\title{
Mean Eulerian Subsurface Currents Measured in the Gulf of Maine and Adjacent Scotian and \\ New England Shelf and Slope Regions, 1974-1980
}

by

R. C. Beardsley

C. A. Mills

Woods Hole Oceanographic Institution

Woods Hole, Massachusetts 02543

P. C. Smith

Atlantic Oceanographic Laboratory Bedford Institute of Oceanography

Dartmouth, Nova Scotia

\author{
B. Butman \\ U.S. Geological Survey \\ Woods Hole, Massachusetts 02543
}

November 1983

Technical Report

Funding was provided by the Department of Interior, Bureau of Land Management under Contract AA 551-MUO-18 and by the National Science Foundation under Grant OCE 80-14941.

Reproduction in whole or in part is permitted for any purpose of the United States Government. This report should be cited as:

Woods Hole Oceanog. Inst. Tech. Rept. WHOI-83-44.

Approved for Distribution

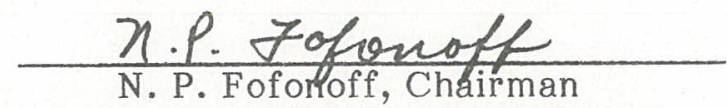

Department of Physical Oceanography 

TABLE OF CONTENTS

Page No.

Abstract

2

1. Introduction

2. Field Program and Support

3. Data Summary

Acknowledgements

References

Appendix A

List of Figures

Table Caption 
$-1-$ 


\section{Abstract}

The Bedford Institute of Oceanography, E.G.\&G., National Marine Fisheries Service, U. S. Geological Survey, and Woods Hole Oceanographic Institution have conducted separate moored array experiments during 1974 1980 to study various aspects of the regional circulation in the Guif of Maine and adjacent Scotian and New England shelf and slope regions.

The mean currents and current variances measured in these experiments are summarized here in tabular and graphical form, together with other information about each experiment. While there have been few measurements made in the interior of the Gulf of Maine, the map of mean subsurface currents demonstrate (a) a net inflow of Scotian shelf water past Cape Sable into the Gulf, (b) a net inflow of slope water through the Northeast Channel into the Gulf, (c) a partially closed anticyclonic circulation around Georges Bank, and (d) a net outflow of shelf water south of Nantucket from the Gulf of Maine into the New England shelf. 
$-3-$ 
1. Introduction

The Bedford Institute of Oceanography, E.G.\&G., the Northeast Fisheries Center of the National Marine Fisheries Service, the U.S. Geological Survey, and the Woods Hole Oceanographic Institution all conducted moored array experiments during 1974-1980 to study different circulation problems in the Gulf of Maine and adjacent Scotian and New England shelf and slope regions. The locations of these experiments are shown in Figure 1 where mooring sites have been sequentially numbered starting on the northern flank of Georges Bank. A detailed description of the mean currents and current statistics measured at Stations 1 through 27 around Georges Bank has been given by Butman et a1. (1982). This report represents an extension of their data base and current statistics to incorporate additional moored array data collected within the Gulf of Maine and in the adjacent shelf regions. Brief descriptions of all the different experiments and their supporting programs are given in the next section, and the mean currents and current variances measured in these experiments are presented in the last section. One objective of this report is to present in compact form the basic moored current data sets obtained in this region during the 1974-1980 period to facilitate new research on regional circulation questions by other investigators.

\section{Field Program and Support}

This report summarizes the mean currents and current statistics measured in the following different field programs. A brief description of each program, principal investigators, station numbers, and supporting agencies is given next for general reference. Also included with each description is a list of the different stations maintained by that program. IOnly those field programs which were conducted on the continental shelf or upper slope are described.)

1. A winter study of current, bottom pressure, and water structure in the western Gulf of Maine (J. A. Vermersch, R. C. Beardsley, and 
W. Brown, 1974-75) conducted with National Science Foundation (NSF) support. NSF Grants to WHOI and UNH; DES 74-03001 and DES 75-03992. Stations 45-47.

2. A long-term current monitoring study initiated in 1975 by the U.S. Geological Survey (USGS) and Woods Hole Oceanographic Institution (WHOI) (R. C. Beardsley, B. Butman and J. A. Vermersch, 1975-76; B. Butman and M. A. Noble, 1977-present). Support from USGS to WHOI: Contracts 14-08-00001-G-197 and 14-08-00001-15615. Support from the U.S. Bureau of Land Management (BLM) to USGS: Memoranda of Understanding (MOU) AA550-MU6-29, AA551-MU8-24, AA551-MU9-4 and AA551MU0-18. Stations $10,11$.

3. A moored array on the New England shelf deployed simultaneously with a pilot Georges Bank current-meter array (R. C. Beardsley, J. A. Vermersch and B. Butman, 1976) conducted with National Science Foundation (NSF) support. NSF Grant to WHOI: OCE 76-01813. BLM MOU to USGS: AA550-MU6-29. Stations 2, 8, 16, 26, 27.

4. A study of bottom currents and sediment transport (B. Butman and M. A. Noble, 1976-present) conducted with BLM support to USGS: MOU AA550-MU6-29, AA551-MU8-24, AA551-MU9-4 and AA551-MU0-18. Stations $7,15,17,24,25$.

5. A long-term study of the currents and hydrographic variability over the outer Scotian shelf and continental slope and upper rise (P. C. Smith and B. D. Petrie, 1975-1978) supported by the Atlantic Oceanographic Laboratory* of the Bedford Institute of Oceanography. Stations 28-35.

*Part of the Ocean Science Surveys branch of the Department of Fisheries and Oceans, Government of Canada. 
6. A long-term study of the low frequency deep flow through the Northeast Channel (R. Schlitz, S. Ramp, W. R. Wright, and J. Vermersch, 1976-78) conducted with National Marine Fisheries Service (NMFS) support. Stations $42-44$.

7. A study of the physical oceanography of Georges Bank (E.G.\&G. Environmental Consultants, R. Scarlet, B. Magne11, D. Frye and C. Flagg: Raytheon Company, D. Cook, 1977-80) supported by BLM. BLM contracts to E.G.\&G.: AA550-CT6-50 and AA551-CT8-46. BLM contracts to Raytheon: AA550-3CT-53 and AA550-CT8-47. Stations 1, 2, 6, 9, 11-14.

8. A study of hydrography and currents on Nantucket Shoals (R. C. Beardsley and R. Limeburner, 1977-79) conducted with Sea Grant support to WHOI: Grants 04-7-158-44104 and 04-8-M01-149. Stations 19-23.

9. A study of currents in Great South Channel (J. A. Vermersch, R. C. Beardsley and B. Butman, 1978-79) conducted with support from USGS and BLM. BLM MOU AA551-MU8-24 and AA551-MU9-4. Stations 15-18.

10. A study of currents on the northern side of Georges Bank as part of the larval herring patch study (R. Schlitz, W. R. Wright, and A. A. Allen, 1978) conducted with National Marine Fisheries Service (NMFS) support. Stations $3-5$.

11. A long-term investigation of the seasonal mean circulation and tidal rectification off southwest Nova Scotia (P. C. Smith, 1978-80) conducted with support of the Atlantic Oceanographic Laboratory of the Bedford Institute of 0ceanography. Stations 36-41. A reduced array at Stations 38-39 has been maintained off Cape Sable for monitoring inflow to the Gulf of Maine (P. C. Smith, 1980-present).

12. A study of low frequency current, bottom pressure and water structure variability over the shelf and upper slope south of Nantucket 
Shoals (R. C. Beardsley, W. R. Wright, S. R. Ramp, R. J. Schlitz, B. Butman, and W. Brown, 1979-80) conducted with NSF, NMFS, and USGS support. NSF grants to WHOI and UNH: OCE 78-19513 and OCE 78-26229. Stations 48-53.

\section{Data Summary}

A time line of a11 moored current measurements made in the experiments described in the last section is shown in Figure 2. The current data at each site have been rotated into a subjectively determined alongshelf and cross-shelf coordinate system and the mean, standard deviation, and subtidal standard deviation of the rotated current components have been computed for all current records of at least one month duration. The coordinate system orientation, current statistics, and mooring information for each site is summarized in Table 1. The standard error of each component was computed using the subtidal standard deviation, the total record length, and an assumed correlation time scale for all data of five days. This procedure undoubtedly underestimates the standard errors in the offshore measurements (e.g., at Stations 29-33) where the characteristic time scales are larger (Smith and Petrie, 1982). However, considering the difficulties involved in estimating these quantities, a uniform value was adopted.

Maps of the mean currents and subtidal standard deviations are shown in Figures 3 and 4 . While most of these measurements were not synoptic (as shown in Figure 2) and there have been few observations made in the western Gulf of Maine, the mean current map demonstrates (a) a net inflow of Scotian shelf water past Cape Sable into the Gulf, (b) a net inflow of slope water through the Northeast Channel into the Gulf, (c) a partially closed anticyclonic (clockwise) circulation around Georges Bank, and (d) a net outflow of shelf water south of Nantucket from the Gulf of Maine into the New England shelf. The reader is referred to Butman et al. (1982) for a description of the general circulation on and around Georges Bank and to Appendix A for a partial list of published references presenting 
analyses of the current data collected in the different moored array experiments described in Section 2.

\section{Acknowledgements}

We would like to gratefully acknowledge the many individuals who have collected and analyzed the data summarized here. This compilation was started during a visit by $P$. C. Smith to WHOI. Support for the final preparation of this report has been provided to B. Butman under BLM Memorandum of Understanding AA 551-MU0-18, to R. C. Beardsley and C. A. Mills from NSF Grant OCE 80-14941, and to P. C. Smith from the Atlantic Oceanographic Laboratory of the Bedford Institute of Oceanography.

\section{References}

Butman, B., R. C. Beardsley, B. Magne11, J. A. Vermersch, D. Frye, R. Schlitz, R. Limeburner, W. R. Wright and M. A. Noble, 1982. Recent observations of the mean circulation on Georges Bank. J. Phys. Oceanogr., 12, 569-591.

Smith, P. C. and B. D. Petrie, 1982. Low-frequency circulation at the edge of the Scotian Shelf. J. Phys. Oceanogr., 12, 28-46. 


\section{APPENDIX A}

A partial 1 ist of references in the published 1 iterature which present analyses of the current data in the different moored array experiments described in Section 2.

\begin{tabular}{|c|c|c|}
\hline $\begin{array}{c}\text { Experiment } \\
\text { Number }\end{array}$ & $\begin{array}{l}\text { Station } \\
\text { Number }\end{array}$ & References \\
\hline 1 & $45-47$ & $\begin{array}{l}\text { Vermersch, J. A., R. C. Beardsley, W. S. Brown, } \\
\text { 1979. Winter circulation in the western Gulf of } \\
\text { Maine: Part 2. Current and pressure observations. } \\
\text { J. Phys. Oceanogr., } 9,768-784 \text {. }\end{array}$ \\
\hline 2 & $10-11$ & $\begin{array}{l}\text { Butman, B., R. C. Beardsley, B. Magnel1, J. A. } \\
\text { Vermersch, D. Frye, R. Schlitz, R. Limeburner, W. } \\
\text { R. Wright and M. A. Noble, 1982. Recent observa- } \\
\text { tions of the mean circulation on Georges Bank. } \\
\text { J. Phys. Oceanogr., 12, 569-591. }\end{array}$ \\
\hline 3 & $\begin{array}{l}26-27 \\
57-60\end{array}$ & $\begin{array}{l}\text { Ou, H. -W., R. C. Beardsley, } 1980 \text {. On the propaga- } \\
\text { tion of free topographic Rossby Waves near contin- } \\
\text { ental margins. Part } 2: \text { Numerical mode1. J. Phys. } \\
\text { Oceanogr., 10, 1323-1339. }\end{array}$ \\
\hline $3-4$ & $\begin{array}{l}2,8,16 \\
7,15 \\
17,24,25\end{array}$ & $\begin{array}{l}\text { Butman, B., R. C. Beardsley, B. Magnel1, J. A. } \\
\text { Vermersch, D. Frye, R. Schlitz, R. Limeburner, } \\
\text { W. R. Wright and M. A. Noble, 1982. Recent ob- } \\
\text { servations of the mean circulation on Georges Bank. } \\
\text { J. Phys. Oceanogr., 12, 569-591. }\end{array}$ \\
\hline \multirow{3}{*}{5} & \multirow{3}{*}{$28-35$} & $\begin{array}{l}\text { Twiche11, D. C., C. D. McClennen, and B. Butman, } \\
\text { 1981. Morphology and processes associated with } \\
\text { accumulation of fine-grained sediment deposits on } \\
\text { the southern New England shelf. J. Sed. Petrol., } \\
\text { 51: } 269-280 \text {. }\end{array}$ \\
\hline & & $\begin{array}{l}\text { Louis, J. P., and P. C. Smith, 1982. The develop- } \\
\text { ment of the barotropic radiation field of an eddy } \\
\text { over a slope. J. Phys. Oceanogr., 12: } 56-73 \text {. } \\
\text { Louis, J. P., B. D. Petrie and P. C. Smith, } 1982 . \\
\text { Observations of topographic Rossby waves on the } \\
\text { continental margin off Nova Scotia. J. Phys. } \\
\text { Oceanogr., 12: } 47-55\end{array}$ \\
\hline & & $\begin{array}{l}\text { Smith, P. C. and B. D. Petrie, 1982. Low-frequency } \\
\text { circulation at the edge of the Scotian shelf. } \\
\text { J. Phys. Oceanogr., } 12: 28-46 \text {. }\end{array}$ \\
\hline
\end{tabular}


Ramp, S. R. and J. A. Vermersch, Jr., 1978. Measurements of the deep currents in the Northeast Channel, Gulf of Maine. I.C.E.S. Document No. C.M. 1978/C:40, 9 pp.

Ramp, S. R. and W. R. Wright, 1979. Northeast Channel Flow: The view after one year's measurements. I.C.E.S. Document No. C.M. 1979/C:54, 17 pp.

Ramp, S. R., R. J. Schlitz, and W. R. Wright, 1979. Northeast Channel Flow and the Georges Bank nutrient budget. I.C.E.S. Document No. C.M. 1980/C:35, $12 \mathrm{pp}$.

Ramp, S. R., R. J. Schlitz, and W. R. Wright, 1982. On the deep transport of mass, heat and nutrients through the Northeast Channel, Guif of Maine. J. Phys. Oceanogr., submitted.

$7 \quad 1,2,6 \quad$ Magne11, B. A., S. L. Spiegel, R. I. Scarlet, J. B. 9,11-14 Andrews, 1980. The relationship between tidal and low-frequency currents on the north slope of Georges Bank. J.Phys. Oceanogr., 10: 1200-1212.

$8 \quad 19-23$

Limeburner, R. and R. C. Beardsley, 1982. The seasonal hydrography and circulation over Nantucket Shoals. Journal of Marine Research, Supplement to $40,37 \overline{1-406}$.

$10 \quad 3-5$

Wright, W. R. and R. G. Lough, 1979). The Georges Bank larval herring patch study of 1978: A preliminary report. I.C.E.S. Document No. C.M. 1979/L:36, $13 \mathrm{pp}$.

11 36-41 Smith, P. C., 1983. The mean and seasonal circulation off southwest Nova Scotia. J. Phys. Oceanogr., in press. 


\section{List of Figures}

Figure 1: Map of Gulf of Maine and adjacent shelf and slope regions showing the station locations occupied in the different moored array experiments conducted in the period 1974-1980. The station numbering scheme shown here is used throughout this report.

Figure 2: Time line of moored current measurements made in the Gulf of Maine and adjacent shelf and slope region during 1975-1980. Dashed lines indicate partial data collection (temperature only, for example). Time lines in brackets indicate data not included in this compilation. The group which made the observations is listed in the first column. BIO is Bedford Institute of Oceanography, EG\&G is EG\&G Environmental Consultants, NMFS is National Marine Fisheries Service, USGS is U.S. Geological Survey and WHOI is Woods Hole Oceanographic Institution. For the BIO and USGS stations, the station designation commonly used by that group is also listed in Column 1. The station number keys the measurements to Table 1 and Figure 1. Groups of measurements made as part of individual field experiments are indicated by large brackets.

Figure 3: Mean Eulerian subsurface currents observed in the Gulf of Maine and adjacent Scotian and New England shelf region. The shallowest current measurements were made at a depth of $10 \mathrm{~m}$, and the mean current vectors shown are not synoptic measurements, but are based on measurements of varying length (one-month minimum) made at different times during the period 1974-1980. Each measurement site is identified by a boldface station number located at the origin of the vector. This station number is the key to the additional data in Table 1. The number in parentheses following the station identifier indicates the water depth in meters at that station. The number at the top 
of the mean velocity vector indicates the measurement depth in meters. The speed scale has been chosen so that the magnitude of the current vector is equivalent to the mean displacement of a water particle during a 6.0 day period.

Figure 4: Standard Deviation of Subtidal Current Components. The subtidal current variability at each station is shown as a cross oriented in the alongshelf/cross-shelf direction where the length of each axis is proportional to the observed standard deviation of the low-frequency current components. The boldface station number keys measurements to Table 1 . The number in parentheses following the station identifier indicates the water depth in meters of that station. The number near the top of the vector indicates the measurement depth in meters. For clarity, only the near-surface and near-bottom values are shown, and some stations have been displaced slightly from their time positions. The speed scale has been chosen so actual water particle excursions at map scale caused by the low-frequency currents are one-half as large as those shown (assuming a typical five-day period for the subtidal motions). 


\section{Table Caption}

Table 1: The data in this table and in Figures 3 and 4 are organized by site number. The primary group that collected the data is indicated in parentheses next to the site number. The instrument type code is: VACM (AMF Vector Averaging Current Meter), 102 (E.G.\&G. Model 102 current meter), 850 (Geodyne Model 850 current meter), ACM (Aanderaa current meter), RAY (Marsh-McBirney electro-magnetic meter mounted on a special buoy fabricated by Raytheon Ocean Systems), BRNCN (Braincon Current Meter), and END (Endeco Model 174 current meter). The mooring code is: S (surface mooring), SS (subsurface mooring), and SPEC (the special Raytheon buoy). The current statistics have been computed at most sites in a subjectively determined alongshelf/crossshelf rotated coordinate system. The coordinate orientation angle $\theta$ indicates the clockwise rotation of the new primed coordinate system, so that $\theta$ is the angle between true North and the new North component, $N^{\prime}$. $E^{\prime}$ and $N^{\prime}$ are aligned with true East and North when $\theta=0$. Both the total standard deviation computed from vector averaged one hour time series and the lowfrequency (LF) standard deviation computed from a low-passed time series are presented. The low-pass filters used typically had a half-power cutoff frequency of 0.03 cycles per hour. The standard error in each component was computed using the LF standard deviation, the record length and an assumed correlation time scale for all data of five days. 


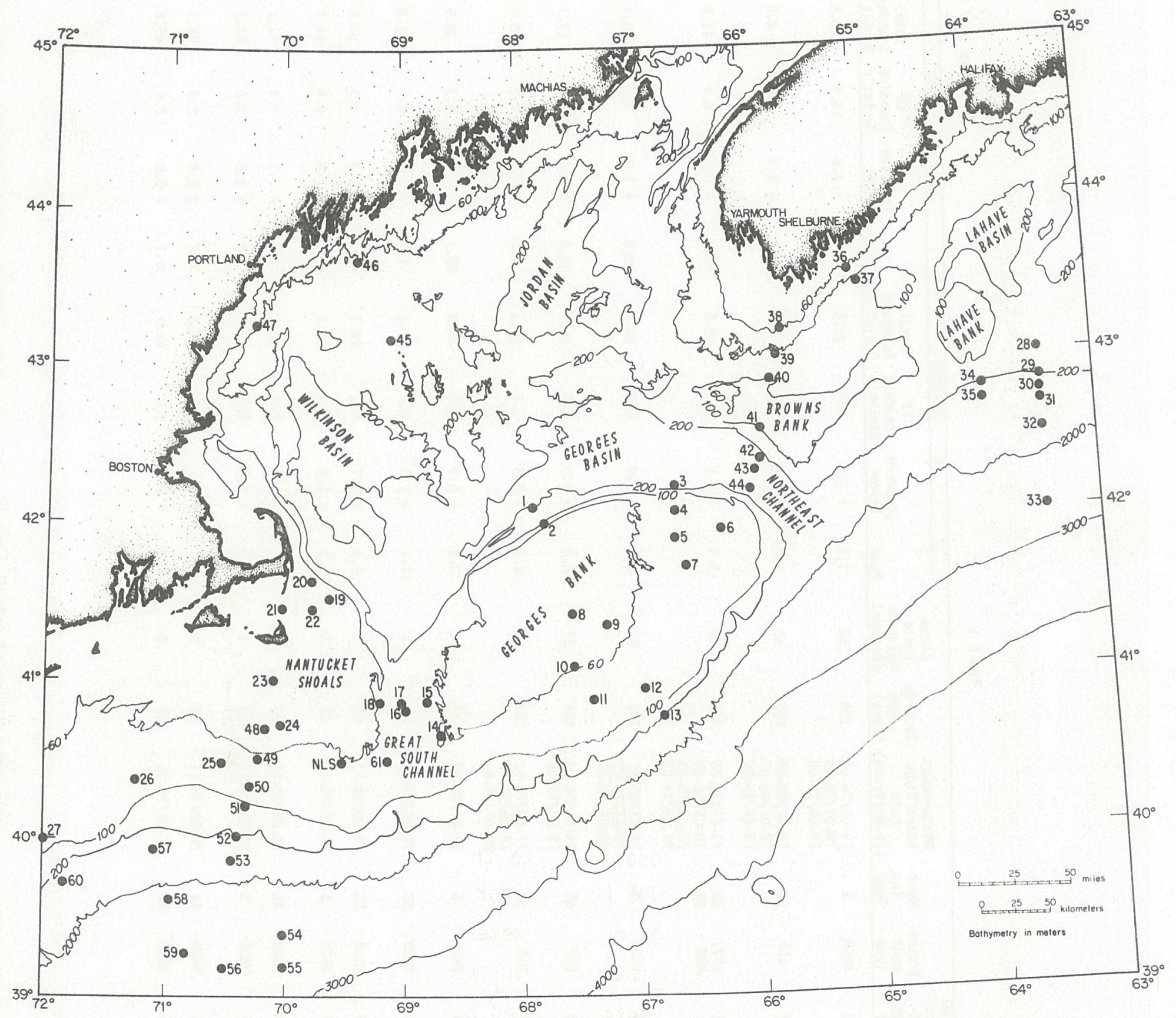

Figure 1: Map of Gulf of Maine and adjacent shelf and slope regions showing the station locations occupied in the different moored array experiments conducted in the period 1974-1980. The station numbering scheme shown here is used throughout this report. 


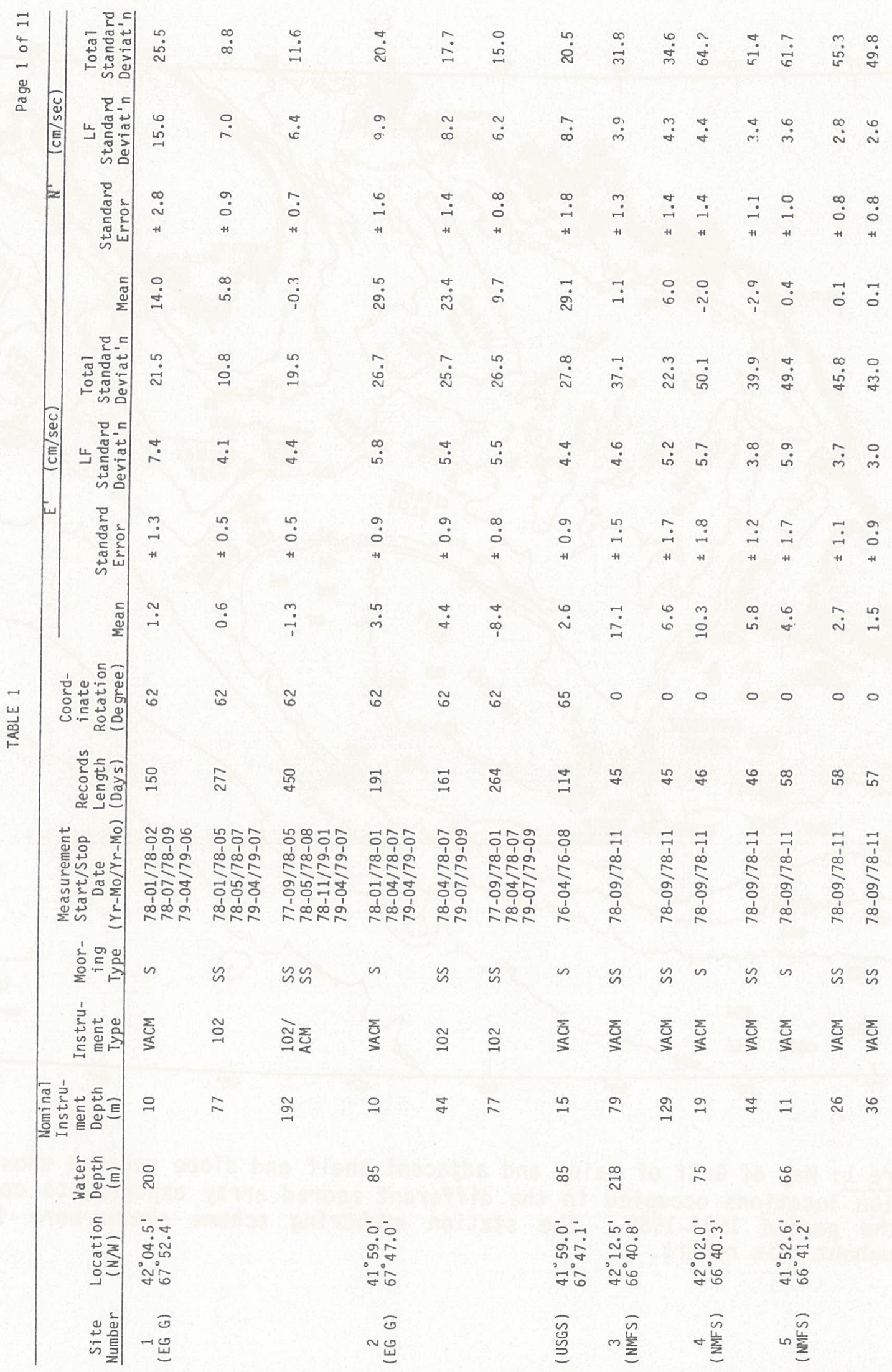




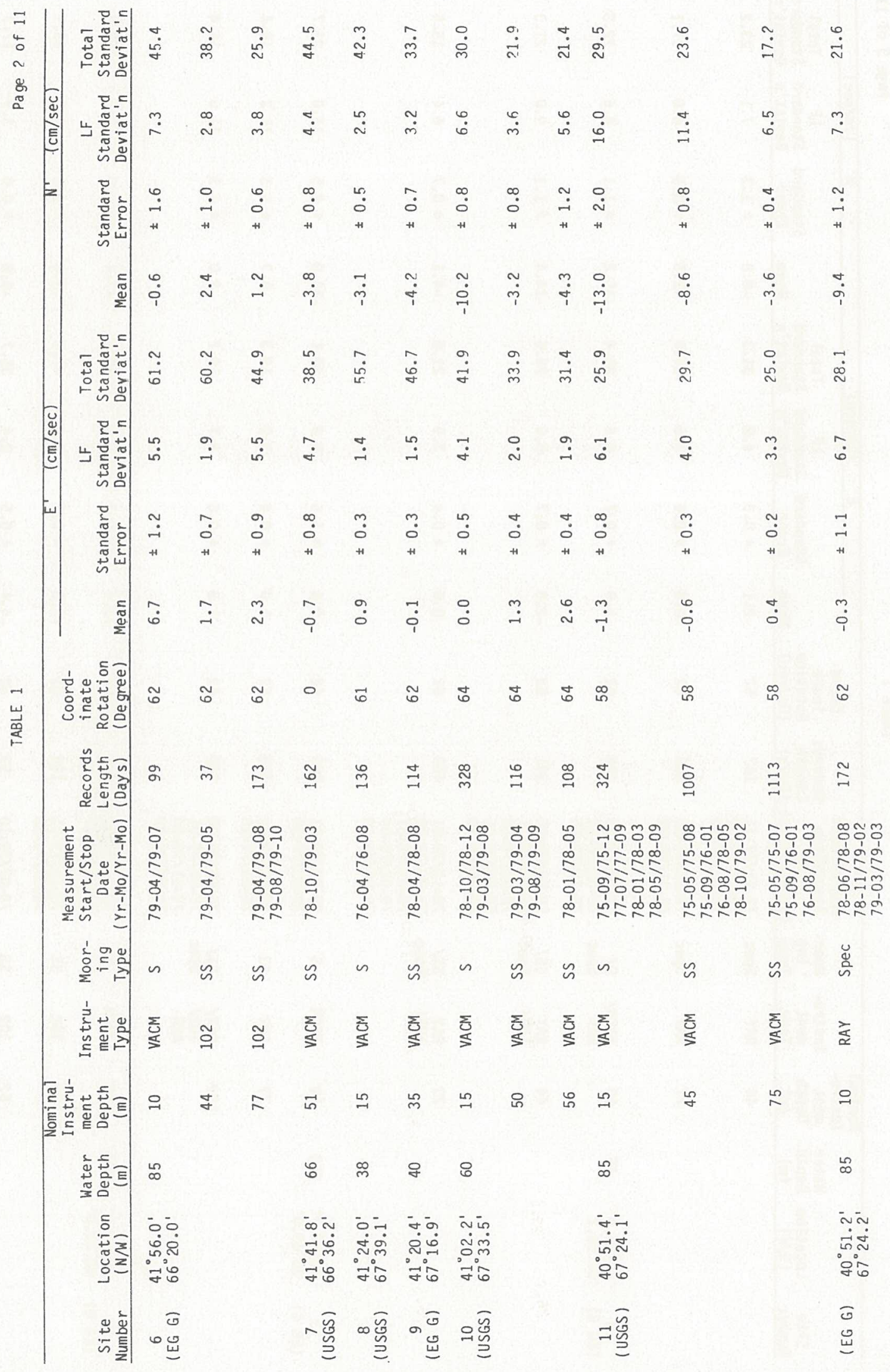




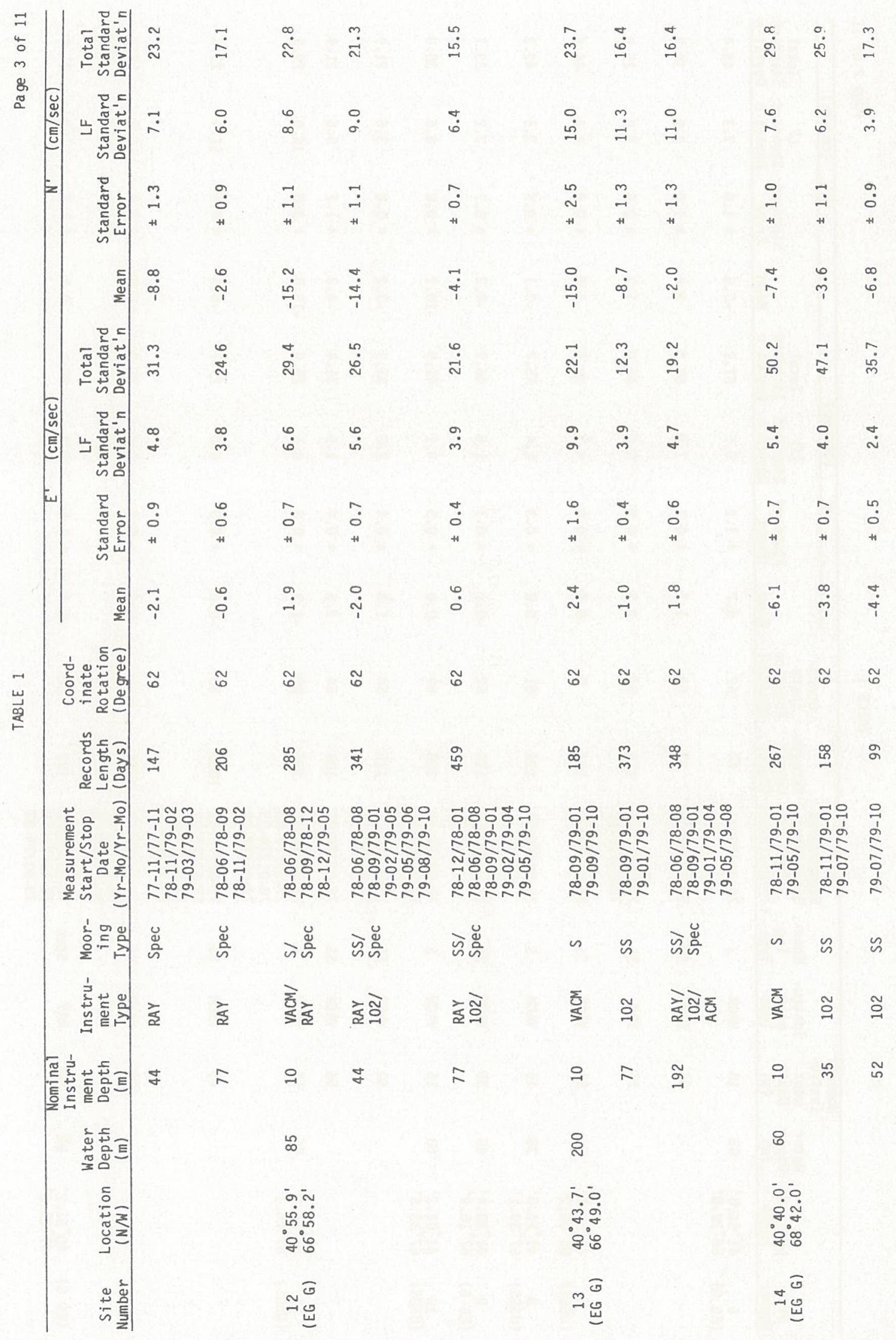




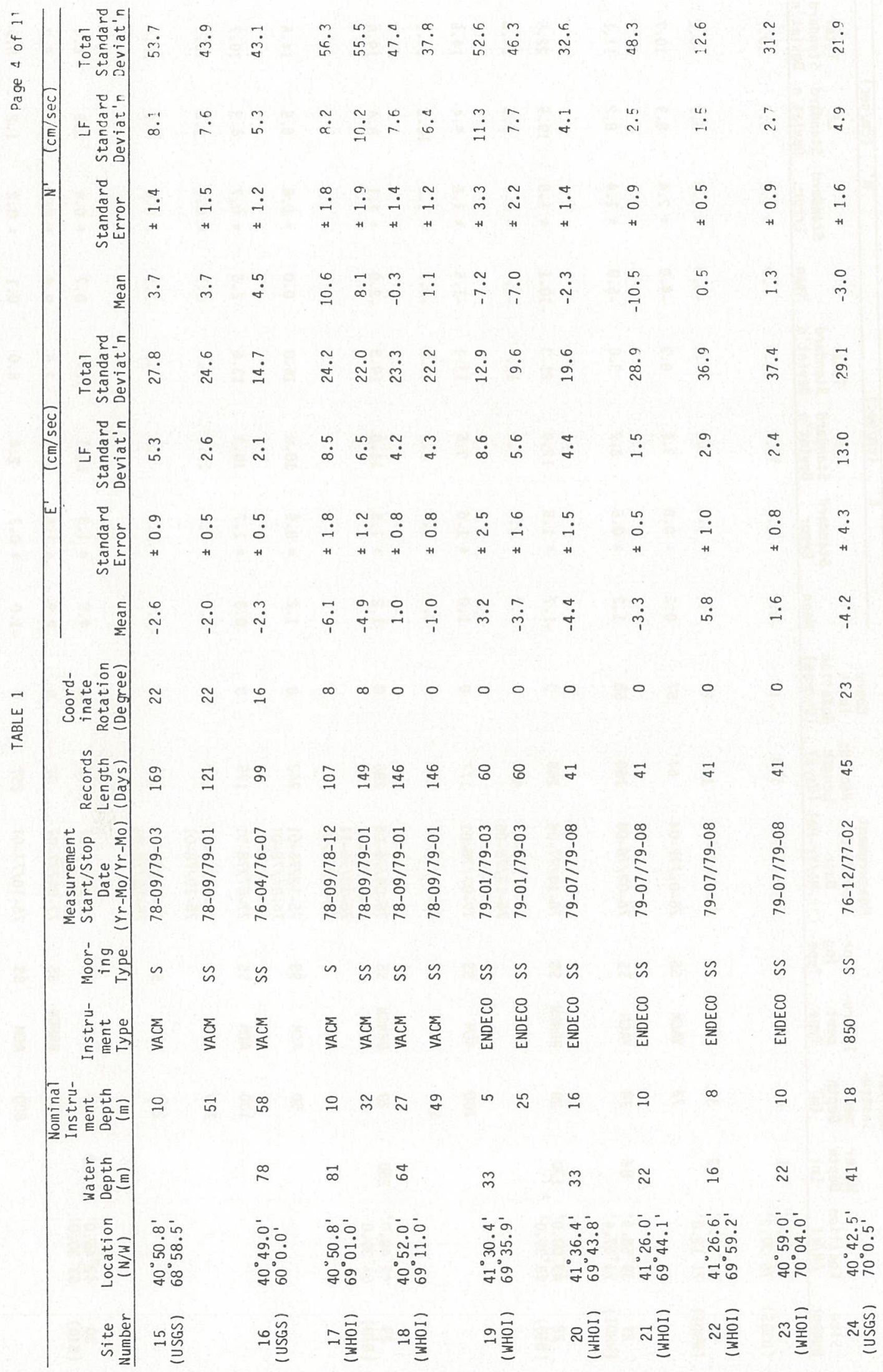




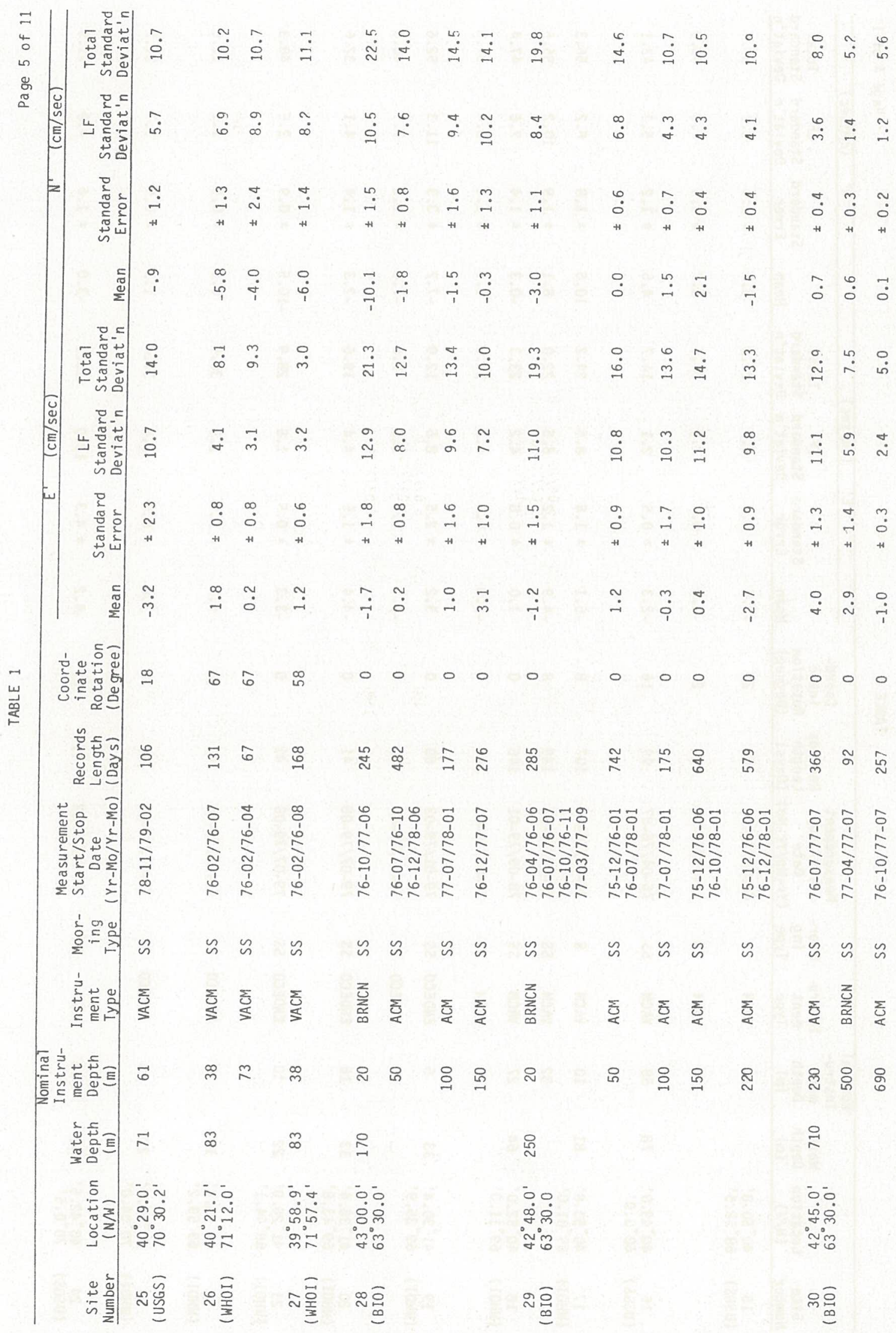




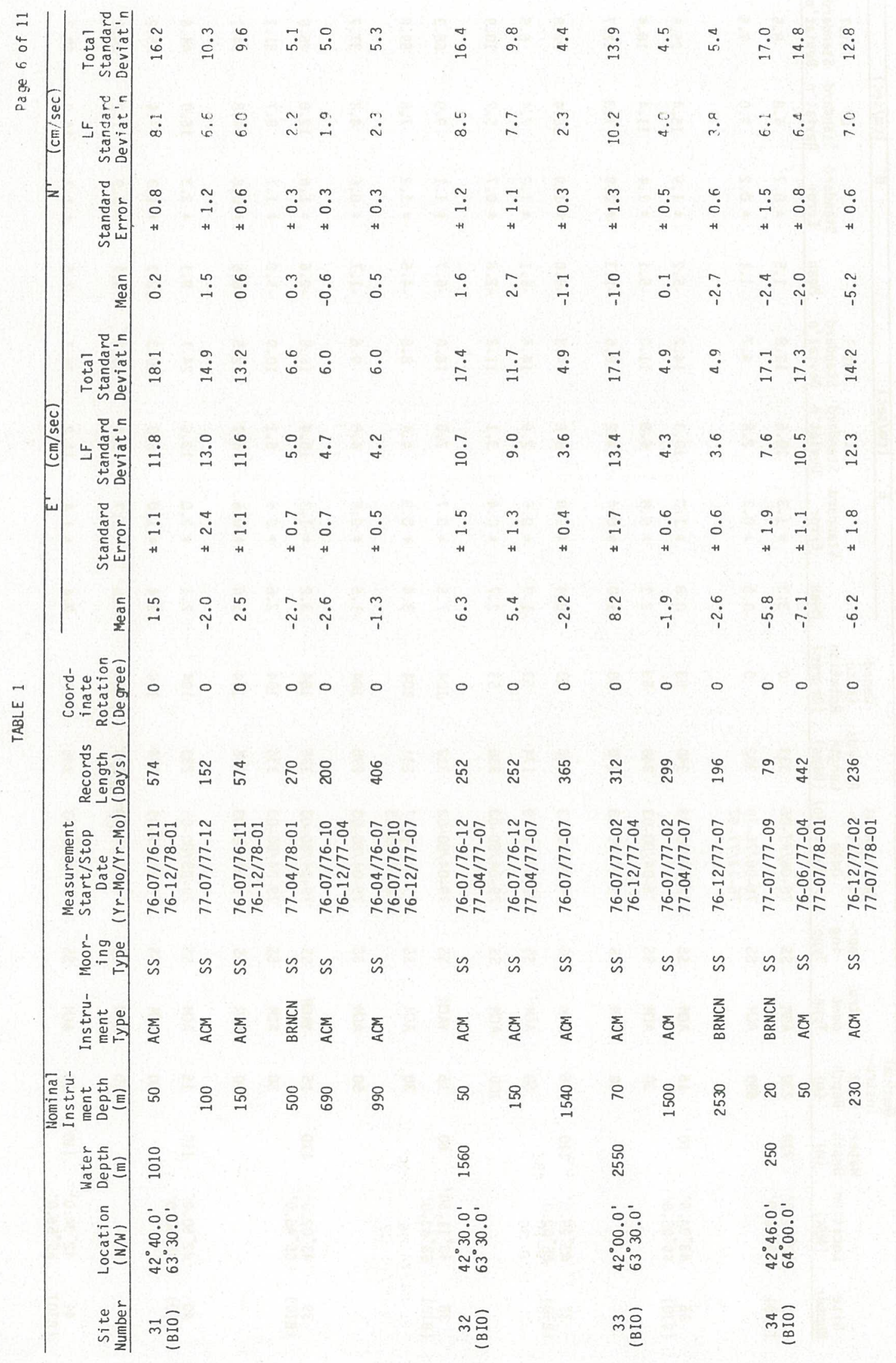




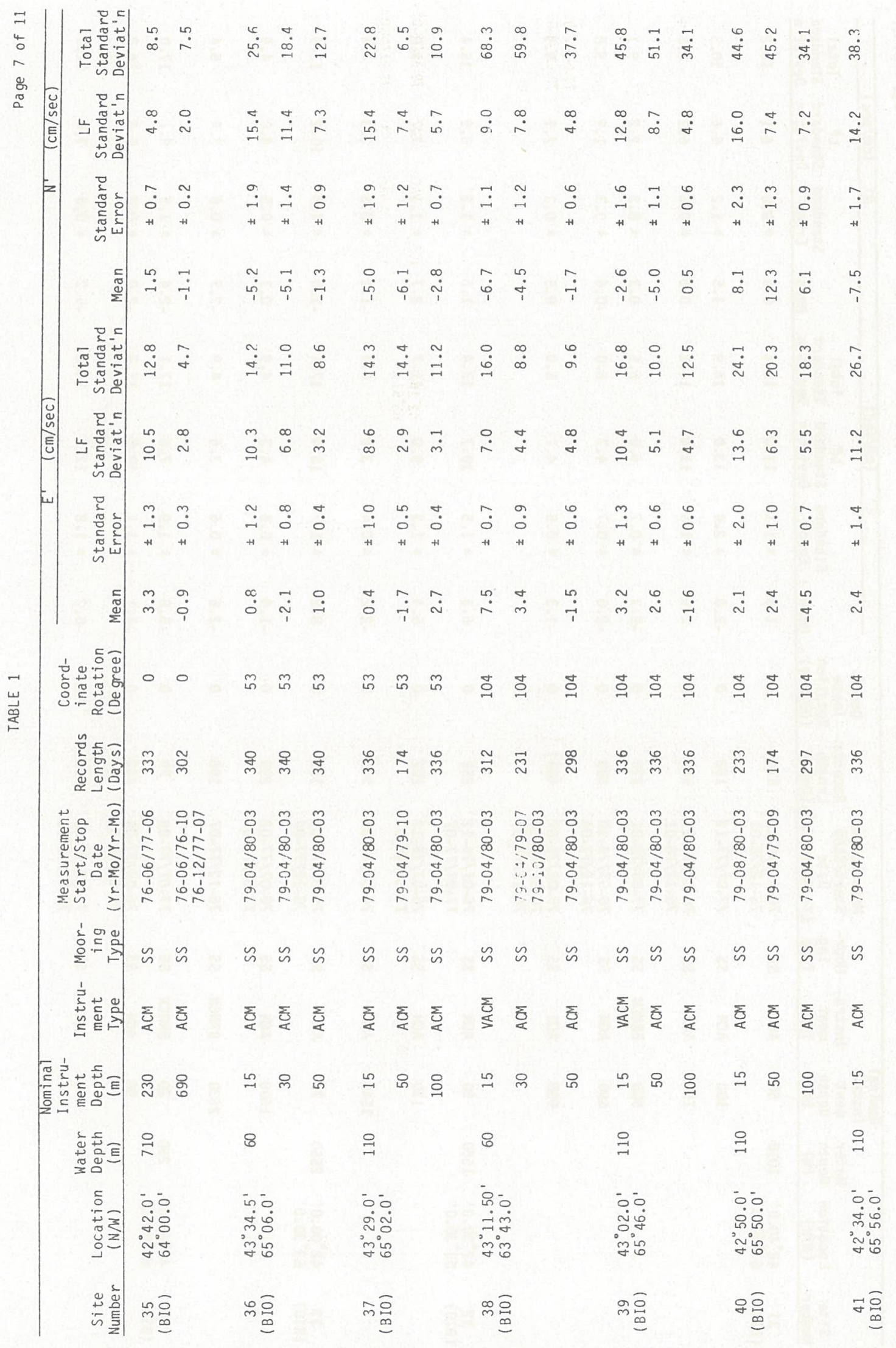




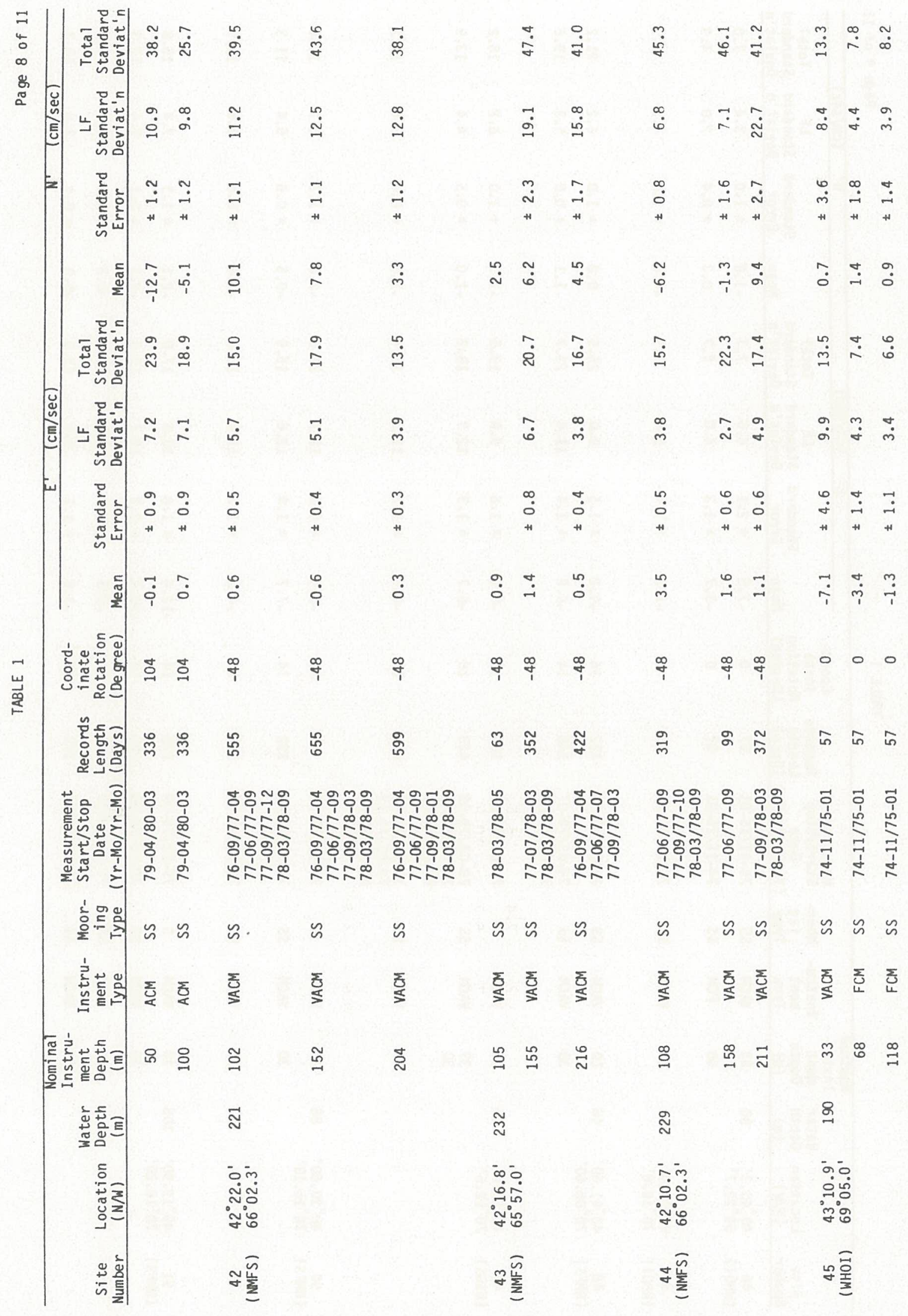




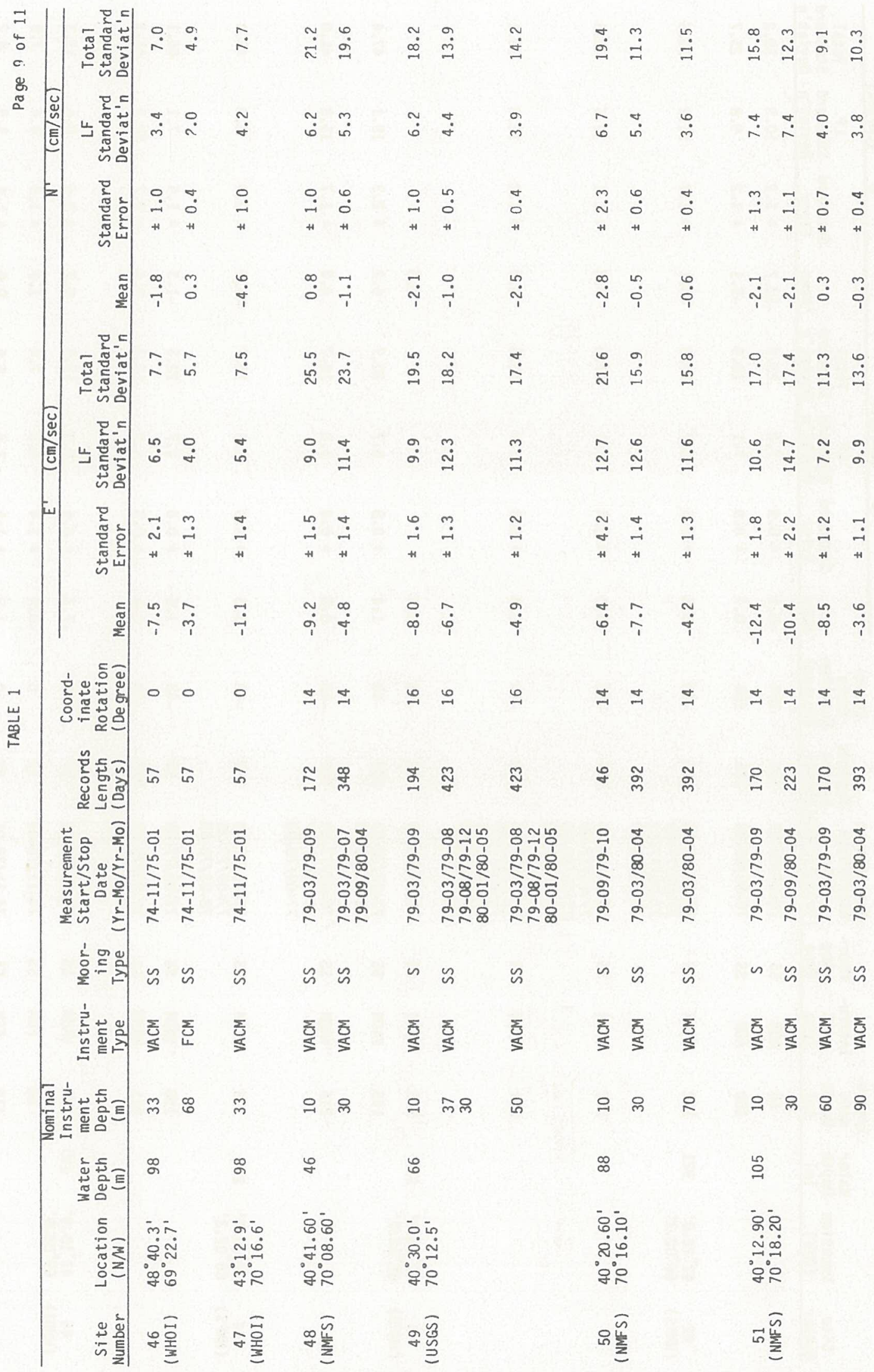




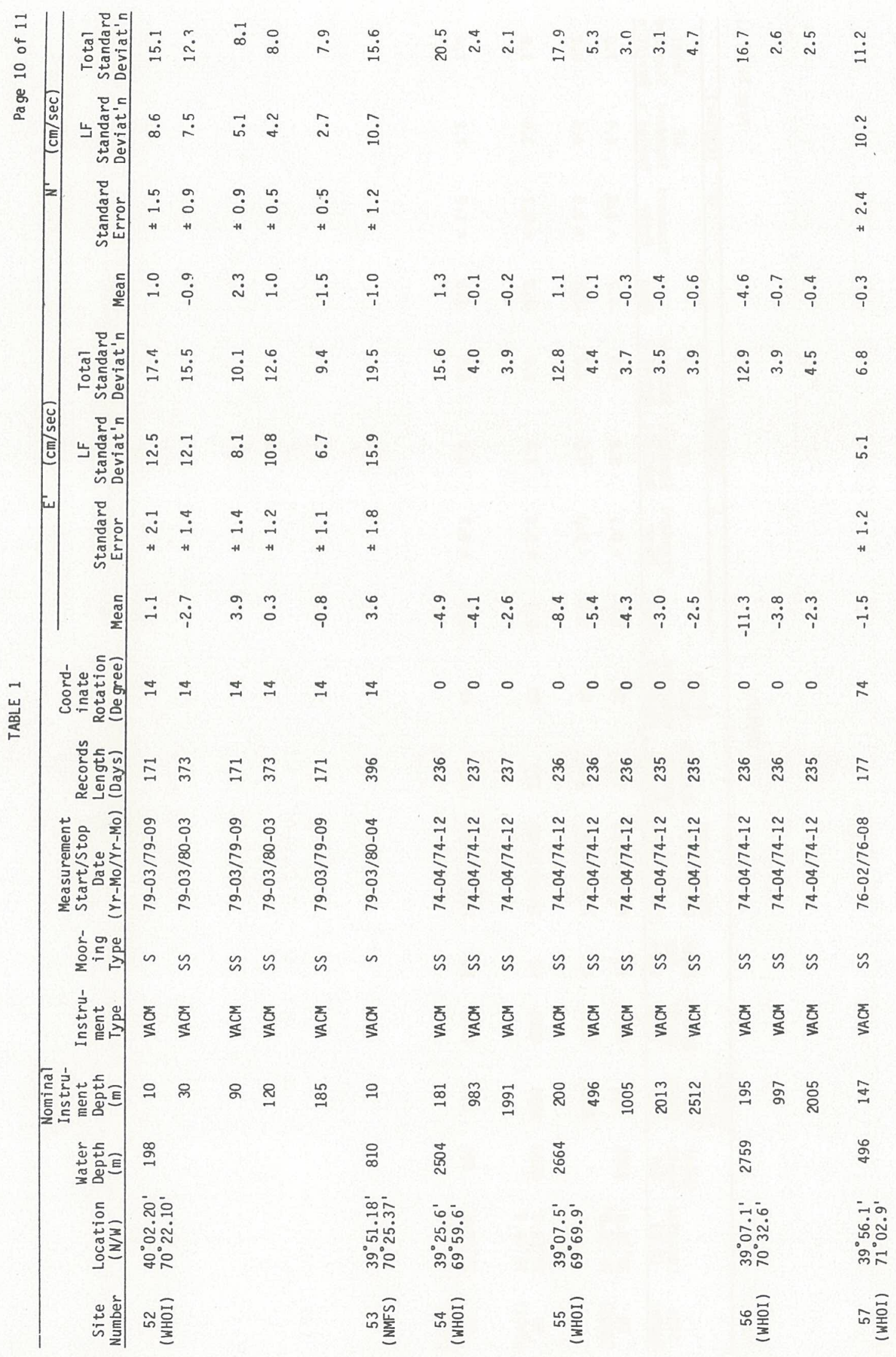




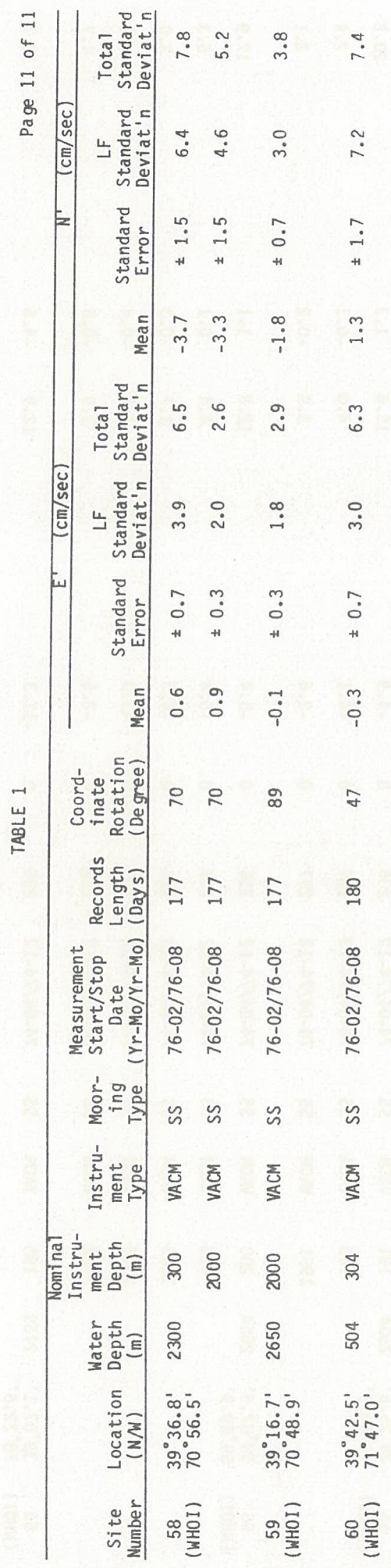




\section{Figure 2}

Time line of moored current measurements made in the Gulf of Maine and adjacent shelf and slope region during 1975-1980. Dashed 1ines indicate partial data collection (temperature only, for example). Time lines in brackets indicate data not included in this compilation. The group which made the observations is listed in the first column. BIO is Bedford Institute of Oceanography, EG\&G is EG\&G Environmenta1 Consultants, NMFS is National Marine Fisheries Service, USGS is U.S. Geological Survey and WHOI is Woods Hole Oceanographic Institution. For the BIO and USGS stations, the station designation commonly used by that group is also listed in Column 1. The station number keys the measurements to Table 1 and Figure 1. Groups of measurements made as part of individual field experiments are indicated by large brackets. 
CURRENT MEASUREMENTS ON GEORGES BANK, GULF OF MAINE AND ADJACENT SHELF AND SLOPE

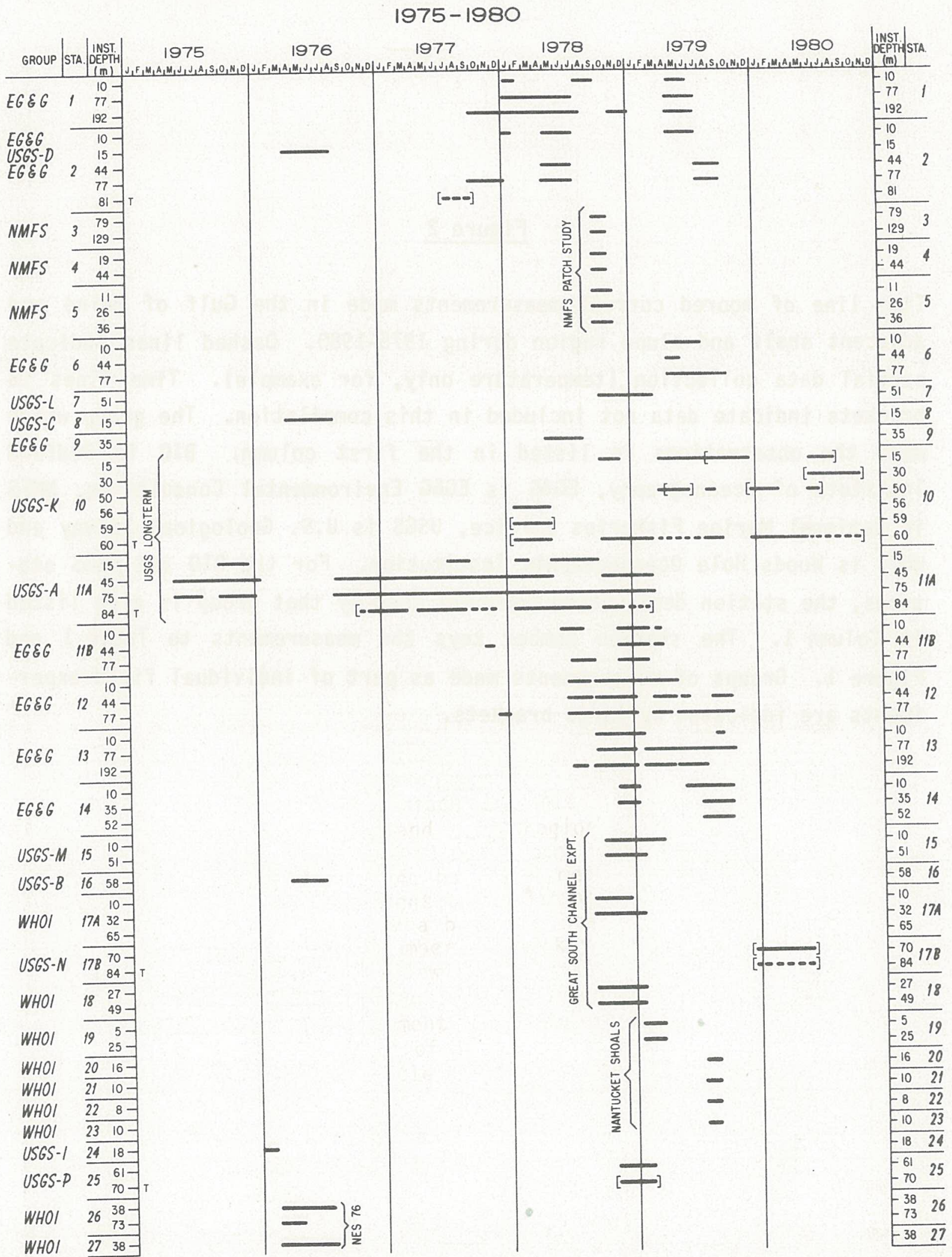




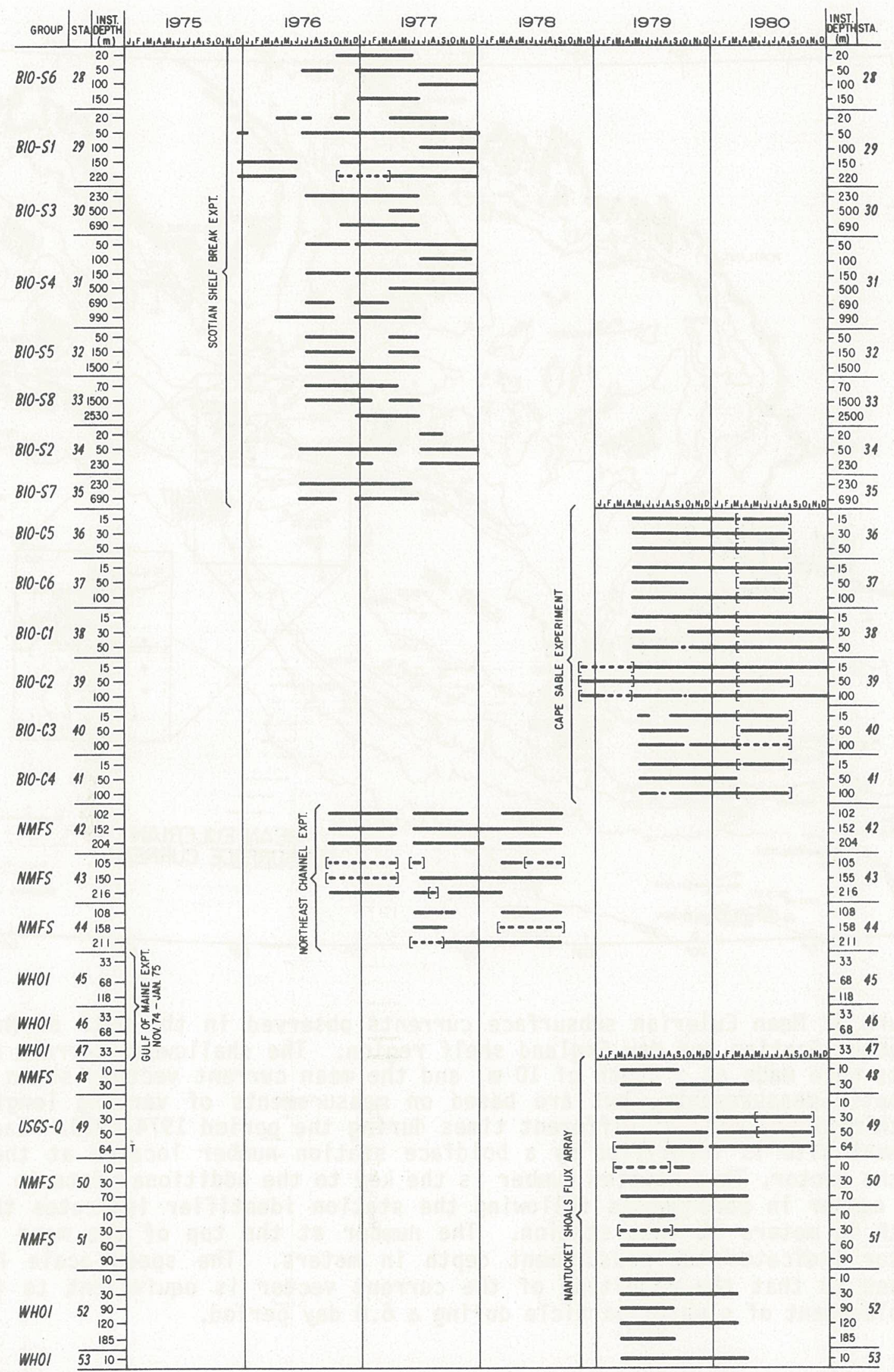




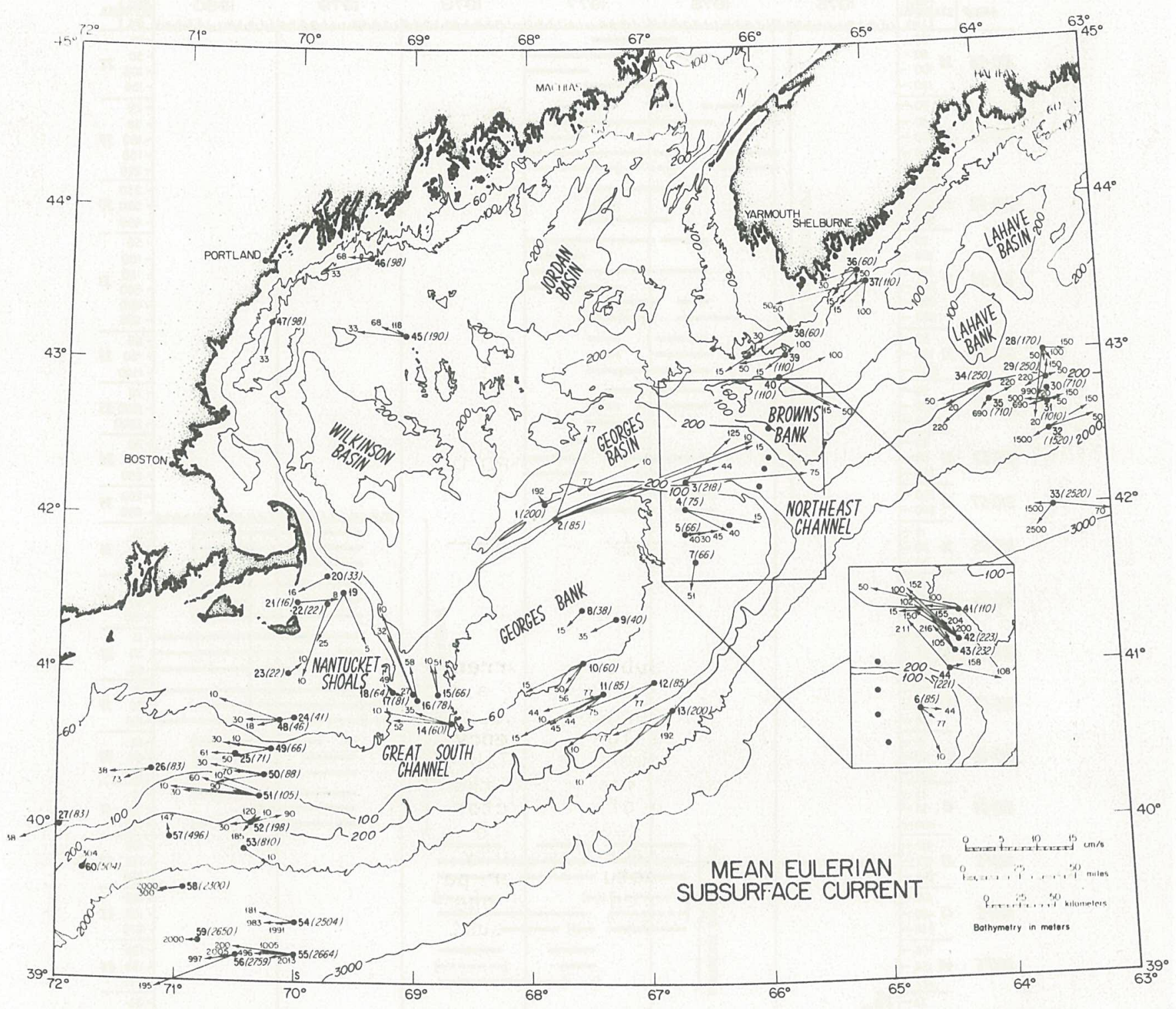

Figure 3: Mean Eulerian subsurface currents observed in the Gulf of Maine and adjacent Scotian and New England shelf region. The shallowest current measurements were made at a depth of $10 \mathrm{~m}$, and the mean current vectors shown are not synoptic measurements, but are based on measurements of varying length (onemonth minimum) made at different times during the period 1974-1980. Each measurement site is identified by a boldface station number located at the origin of the vector. This station number is the key to the additional data in Table 1. The number in parentheses following the station identifier indicates the water depth in meters at that station. The number at the top of the mean velocity vector indicates the measurement depth in meters. The speed scale has been chosen so that the magnitude of the current vector is equivalent to the mean displacement of a water particle during a 6.0 day period. 


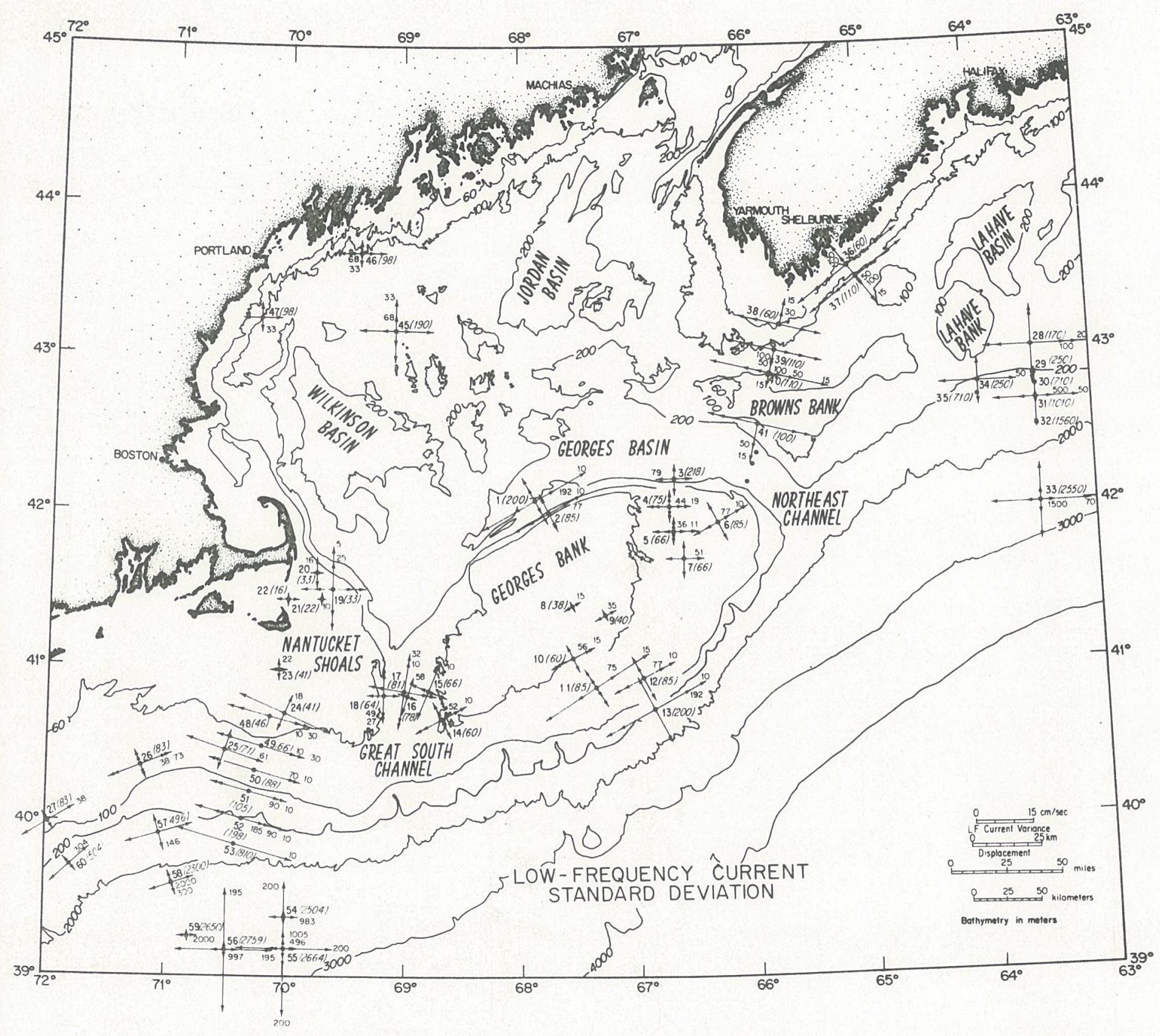

Figure 4: Standard Deviation of Subtidal Current Components. The subtidal current variability at each station is shown as a cross oriented in the alongshelf/ cross-shelf direction where the length of each axis is proportional to the observed standard deviation of the low-frequency current components. The boldface station number keys measurements to Table 1. The number in parentheses following the station identifier indicates the water depth in meters of that station. The number near the top of the vector indicates the measurement depth in meters. For clarity, only the near-surface and near-bottom values are shown, and some stations have been displaced slightly from their time positions. The speed scale has been chosen so actual water particle excursions at map scale caused by the low-frequency currents are one-half as large as those shown (assuming a typical five-day period for the subtidal motions). 


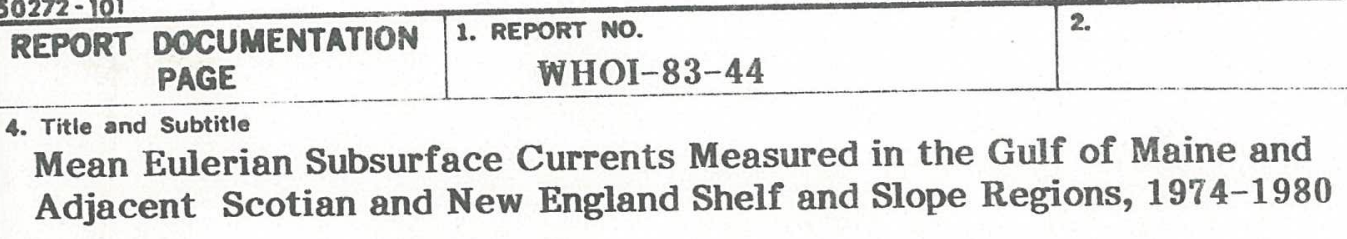

7. Author(s)

R.C. Beardsley, C.A. Mills, P.C. Smith and B. Butman

9. Performing Organization Name and Address

Woods Hole Oceanographic Institution

Woods Hole, Massachusetts 02543

3. Recipient's Accession No.

5. Raport Date

November 1983

6.

8. Performing Organization Rept. No.

WHOI-83-44

10. Project/Task/Work Unit No.

11. Contract(C) or Grant(G) No.

(C) AA 551-MUO-18

(G)

OCE 80-14941

13. Type of Report \& Period Covered

Technical

14.

The National Science Foundation

This report should be cited as: Woods Hole Oceanog. Inst. Tech. Rept. WHOI-83-44

16. Abstract (Limit: 200 words)

The Bedford Institute of Oceanography, E.G.\&.G., National Marine Fisheries Service, U.S. Geological Survey, and Woods Hole Oceanographic Institution have conducted separate moored array experiments during 1974-1980 to study various aspects of the regional circulation in the Gulf of Maine and adjacent Scotian and New England shelf and slope regions.

The mean currents and current variances measured in these experiments are summarized here in tabular and graphical form, together with other information about each experiment. While there have been few measurements made in the interior of the Gulf of Maine, the map of mean subsurface currents demonstrate (a) a net inflow of Scotian shelf water past Cape Sable into the Gulf, (b) a net inflow of slope water through the Northeast Channel into the Gulf, (c) a partially closed anticyclonic circulation around Georges Bank, and (d) a net outflow of shelf water south of Nantucket from the Gulf of Maine into the New England shelf.

17. Document Analysis a. Descriptors

1. Currents

2. Gulf of Maine

3. Circulation

b. Identifiers/Open-Ended Terms

c. COSATI Field/Group

18. Availability Statemen:

Unlimited distribution

19. Security Class (This Report)

Unclassified

20. Security Class (This Page)
21. No. of Pages 31

22. Price 



\title{
DOCUMENT LIBRARY
}

\author{
February 1, 1984 \\ DISTRIBUTION LIST \\ BIBLIOGRAPHY AND TECHNICAL REPORT EXCHANGE
}

Library

R.S.M.A.S.

University of Miami

4600 Rickenbacker Causeway

Miami, FL 33149

Fisheries-Oceanography Library

151 Oceanography Teaching Bldg.

University of Washington

Seattle, WA 98195

Institute of Marine Sciences Library

University of Alaska

O'Neill Building

905 Koyukuk Ave. North

Fairbanks, AK 99701

Pell Marine Science Library

University of Rhode Island

Narrangansett Bay Campus

Narrangansett, R.I. 02882

Institute of Geophysics

University of Hawaii

Library Room 252

2525 Correa Rd.

Honolulu, HI 96822

NOAA/EDIS Miami Library Center

4301 Rickenbacker Causeway

Miami, FL 33149

Library

Chesapeake Bay Institute

4800 Atwell Rd.

Shady Side, MD 20867

Working Collection

Texas A \& M University

Dept. of Oceanography

College Station, TX 77843
Hancock Library of Biology \& Oceanography

Alan Hancock Laboratory

University of Southern California

Los Angeles, CA 90007

Library

Lamont-Doherty Geological Observatory

Columbia University

Palisades, NY 10964

Library

Physical Oceanographic Laboratory

Nova University

8000 N. Ocean Drive

Dania, FL 33304

Library

Skidaway Institute of Oceanography

P. O. Box 13687

Savannah, GA 31406

U.S. Coast Guard Oceanographic Unit Library Bldg. 159 E. Navy Yard Annex

Washington, DC 20590

Library

Virginia Institute of Marine Science

Gloucester Point, VA 23062

MIT Libraries

Serial Journal Room 14E-210

Cambridge, MA 02139

Director, Ralph M. Parsons Laboratory

Room 48-311

MIT

Cambridge, MA 02139

Marine Resources Information Center

Bldg E38-320

MIT

Cambridge, MA 02139

Attn: Stella Sanchez-Wade

Documents Section

Scripps Institute of Oceanography

Library, Mail Code C-075C

La Jolla, CA 92093 
